\title{
The effects of heat stress on protein metabolism in lactating Holstein cows
}

\author{
S. T. Gao, ${ }^{*}$ J. Guo, ${ }^{*}$ S. Y. Quan, ${ }^{*}$ X. M. Nan, ${ }^{*}$ M. V. Sanz Fernandez,† L. H. Baumgard,† and D. P. Bu* $\ddagger \S^{1}$ \\ *State Key Laboratory of Animal Nutrition, Institute of Animal Science, Chinese Academy of Agricultural Sciences, Beijing 100193, China \\ †Department of Animal Science, lowa State University, Ames 50014 \\ ¥Chinese Academy of Agricultural Sciences-World Agroforestry Centre (CAAS-ICRAF) Joint Lab on Agroforestry \\ and Sustainable Animal Husbandry, World Agroforestry Centre, East and Central Asia, Beijing 100193, China \\ $\S$ Hunan Co-Innovation Center of Safety Animal Production (CICSAP), Changsha, Hunan 410128, China
}

\begin{abstract}
Heat stress (HS) decreases milk protein synthesis beyond what would be expected based on the concomitant reduction in feed intake. The aim of the present study was to evaluate the direct effects of HS on milk protein production. Four multiparous, lactating Holstein cows $(101 \pm 10 \mathrm{~d}$ in milk, $574 \pm 36 \mathrm{~kg}$ of body weight, $38 \pm 2 \mathrm{~kg}$ of milk/d) were individually housed in environmental chambers and randomly allocated to 1 of 2 groups in a crossover design. The study was divided into 2 periods with 2 identical experimental phases (control phase and trial phase) within each period. During phase 1 or control phase $(9 \mathrm{~d})$, all cows were housed in thermal neutral conditions $\left(\mathrm{TN} ; 20^{\circ} \mathrm{C}\right.$, $55 \%$ humidity) and fed ad libitum. During phase 2 or treatment phase (9 d), group 1 was exposed to cyclical HS conditions ( 32 to $36^{\circ} \mathrm{C}, 40 \%$ humidity) and fed ad libitum, whereas group 2 remained in TN conditions but was pair-fed (PFTN) to their HS counterparts to eliminate the confounding effects of dissimilar feed intake. After a 30-d washout period in TN conditions, the study was repeated (period 2), inverting the environmental treatments of the groups relative to period 1: group 2 was exposed to HS and group 1 to PFTN conditions. Compared with PFTN conditions, HS decreased milk yield $(17.0 \%)$, milk protein $(4.1 \%)$, milk protein yield (19\%), $4 \%$ fat-corrected milk $(23 \%)$, and fat yield (19\%). Apparent digestibility of dry matter, organic matter, neutral detergent fiber, acid detergent fiber, crude protein, and ether extract was increased (11.1-42.9\%) in HS cows, as well as rumen liquor ammonia (before feeding 33.2\%; after feeding 29.5\%) and volatile fatty acid concentration (45.3\%) before feeding. In addition, ruminal $\mathrm{pH}$ was reduced (9.5 and $6 \%$ before and after feeding, respectively) during HS. Heat stress decreased plasma free amino acids (AA; 17.1\%) and tended to increase and increased blood, urine, and milk urea nitrogen $(17.2,243$, and $24.5 \%$, respectively).
\end{abstract}

Received August 24, 2016.

Accepted February 23, 2017.

${ }^{1}$ Corresponding author: budengpan@126.com
Further, HS cows had reduced plasma glucose (8\%) and nonesterified fatty acid (39.8\%) concentrations compared with PFTN controls. These data suggest that HS increases systemic AA utilization (e.g., decreased plasma AA and increased nitrogen excretion), a scenario that limits the AA supply to the mammary gland for milk protein synthesis. Furthermore, the increase in AA requirements during HS might represent the increased need for gluconeogenic precursors, as HS is thought to prioritize glucose utilization as a fuel at the expense of nonesterified fatty acids.

Key words: heat stress, milk protein, restricted intake, milk protein precursor, protein metabolism

\section{INTRODUCTION}

Heat stress (HS) induces behavioral and metabolic changes in cattle that are intended to maintain homeothermy (West, 1994), often at the expense of decreased productivity and profitability. For instance, HS animals reduce DMI, activity, and metabolic rate in an attempt to decrease metabolic heat production (NRC, 2001). In dairy cattle, HS decreases milk yield (Bandaranayaka and Holmes, 1976; Rhoads et al., 2009; Wheelock et al., 2010; Cowley et al., 2015), which has been traditionally attributed to the heat-induced reduction in DMI (Fuquay, 1981; Beede and Collier, 1986; West, 2003). However, the utilization of pair-fed thermal neutral (PFTN) controls demonstrated that reduced DMI only partially (about 50\%) explains the decrease in productivity, suggesting that hyperthermia itself directly affects milk production (Bandaranayaka and Holmes, 1976; Wheelock et al., 2010; Cowley et al., 2015).

Milk composition is also discordantly altered during hyperthermia, which indicates that HS regulates component synthesis in addition to its overall effect on milk yield (Bernabucci et al., 2015; Cowley et al., 2015). For instance, HS decreases milk protein content and yield, but the involved mechanisms remain largely unknown. Rhoads et al. (2009) suggested that modest changes in the somatotropic axis may explain a small portion of the reduction in milk protein yield during HS. Further, Cowley et al. (2015) demonstrated that the heat- 
Table 1. Experimental design

\begin{tabular}{|c|c|c|c|c|c|}
\hline Treatment & \multicolumn{2}{|c|}{ Period 1 (18 d) } & $\begin{array}{l}\text { Wash-out period } \\
\qquad(30 \mathrm{~d})\end{array}$ & \multicolumn{2}{|c|}{ Period $2(18 \mathrm{~d})$} \\
\hline Heat stress & - & Group 1 & - & - & Group 2 \\
\hline \multirow[t]{2}{*}{ Thermal neutral and ad libitum } & Group 1 & - & Group 1 & Group 1 & - \\
\hline & Group 2 & & Group 2 & Group 2 & \\
\hline
\end{tabular}

induced reduction in milk protein of heat-stressed cows is the result of the specific downregulation of mammary protein synthetic activity and not an artifact of the overall milk yield reduction. Understanding the biology behind the adaptation to hyperthermia is critical to develop management, nutritional, and pharmacological strategies to mitigate its deleterious effects on productivity. The current study objective was to elucidate the mechanisms by which HS directly reduces milk protein concentration. For this purpose, we investigated HS effects on production, digestibility, rumen fermentation, and blood/urine nitrogen parameters relative to PFTN controls.

\section{MATERIALS AND METHODS}

\section{Animals and Experimental Design}

Animals were handled and cared for following the guidelines of the Institute of Animal Science, Chinese Academy of Agricultural Sciences. Four multiparous, lactating Holstein cows $(101 \pm 10$ DIM, $574 \pm 36 \mathrm{~kg}$ of $\mathrm{BW}, 38 \pm 2 \mathrm{~kg}$ of milk/d, second parity, 1-2 mo pregnant) were individually housed in environmental chambers and randomly allocated to 1 of 2 groups in a $2 \times 2$ crossover design (Table 1 ). The study was divided into 2 periods (period 1 and period 2) with 2 identical experimental phases (control phase and trial phase) within each period. During phase 1 or control phase $(9 \mathrm{~d})$, all cows were in thermal neutral conditions $\left[\mathbf{T N} ; 20^{\circ} \mathrm{C}, 55 \%\right.$ humidity; temperature-humidity index $(\mathbf{T H I})=65.5]$ and fed ad libitum. During phase 2 or treatment phase $(9 \mathrm{~d})$, group $1(\mathrm{n}=2)$ was exposed to cyclical HS conditions $\left(0600-1800 \mathrm{~h}\right.$ at $36^{\circ} \mathrm{C}, 1800-0600$ $\mathrm{h}$ at $32^{\circ} \mathrm{C}, 40 \%$ humidity; $\left.\mathrm{THI}=84.5\right)$ and fed ad libitum, whereas group 2 remained in TN conditions but was pair-fed (PFTN) to their HS counterparts. To calculate the amount of feed offered to the PFTN cows based on the intake of HS cows, the trial (sampling and feed restriction) started and ran $1 \mathrm{~d}$ behind HS cows for the PFTN cows as previously described (Wheelock et al., 2010). For the pair-feeding calculations, the ad libitum control phase daily feed intake was averaged for each cow and used as a baseline. For each HS cow, the decrease in feed intake during the treatment phase was calculated as the percentage of feed intake reduction relative to the control phase for each day of HS exposure. This percentage of feed intake reduction was averaged for all the HS cows per day of exposure and applied individually to the baseline of each PFTN cow. After a 30-d washout period in TN conditions, the study was repeated (period 2), inverting the environmental treatments of the groups relative to the treatment phase in period 1 . Cows were kept in a $12 \mathrm{~h}$ light:12 h dark cycle and allowed to drink water ad libitum. Cows were fed a TMR formulated to meet or exceed the predicted requirements (NRC, 2001) of energy, protein, minerals, and vitamins (Table 2). All cows were individually fed twice daily (0500 and 1700 h) and orts were recorded daily before the morning feeding. During the treatment phase, calculated feed for the PFTN animals was divided in 2 and offered following the same schedule. Throughout the experiment, cows were milked twice daily $(0500$ and $1700 \mathrm{~h})$ and milk yields were recorded at each milking.

\section{Sampling}

Feed samples from the morning TMR and the orts were collected on d 2, 4, 6, and 8 of each phase, composited, and frozen at $-20^{\circ} \mathrm{C}$ for further analysis. Body weight was measured $1 \mathrm{~d}$ before and at the end of each period, using a weighbridge (Mettler Toledo Ltd., Zurich, Switzerland).

On d 5 and 6 of each phase, total urine and feces were collected separately. Urine was obtained using a device that covered the vulva (but not the anus) connected through a tube to a collection container. To increase the accuracy of urine nitrogen content, we measured the collected volume every $4 \mathrm{~h}$ and stored $10 \%$ of the urine (the remainder was discarded) at $4^{\circ} \mathrm{C}$. At the end of the 2-d sampling period, we mixed all the urine per cow and sampled $50 \mathrm{~mL}$ that was acidified with 0.5 $\mathrm{mL}$ of $6 \mathrm{M} \mathrm{HCl}$. Feces excreted during the $24 \mathrm{~h}$ were weighed in the morning, homogenized, sampled $(\sim 400$ $\times g$ ), and stored at $4^{\circ} \mathrm{C}$ until the end of the feces sampling. At the end of the 2-d sampling period, we mixed all the sampled feces per cow and re-sampled. For CP determination, $\sim 200 \mathrm{~g}$ of feces were acidified with 20 
Table 2. Ingredients and chemical composition of $\operatorname{diets}^{1}$

\begin{tabular}{lr}
\hline Item & Value \\
\hline Ingredient (\% of DM) & \\
Alfalfa hay & 23.98 \\
Extruded soybean & 2.08 \\
Whole corn silage & 26.02 \\
Steam-flaked corn & 21.99 \\
Bean pulp & 11.38 \\
Rapeseed meal & 4.22 \\
Feeding corn meal ${ }^{2}$ & 8.19 \\
Limestone & 1.19 \\
Salt & 0.38 \\
Supplement & 0.57 \\
Chemical analysis $(\%$ of DM) & \\
ADF & 23.28 \\
NDF & 39.31 \\
CP & 15.64 \\
OM & 93.21 \\
Ether extract & 2.33 \\
NE & (Mcal/kg of DM) \\
\hline
\end{tabular}

${ }^{1}$ Values represent an average of samples collected and composited throughout the trial. Diet DM averaged $54.2 \%$.

${ }^{2}$ Flour made with corn.

${ }^{3}$ Contained (per kilogram of DM) a minimum of 250,000 IU of vitamin A; 65,000 IU of vitamin D; 2,100 IU of vitamin E; $400 \mathrm{mg}$ of Fe; 540 $\mathrm{mg}$ of $\mathrm{Cu} ; 2,100 \mathrm{mg}$ of $\mathrm{Zn} ; 560 \mathrm{mg}$ of $\mathrm{Mn} ; 15 \mathrm{mg}$ of Se; $35 \mathrm{mg}$ of I; and $68 \mathrm{mg}$ of Co.

$\mathrm{mL}$ of $6 \mathrm{M} \mathrm{HCl}$. The remaining $\sim 200-\mathrm{g}$ samples were kept for other nutrient analysis. Both urine and feces samples were stored frozen at $-20^{\circ} \mathrm{C}$ until analysis. Daily milk samples from each cow were obtained by mixing samples from both the morning and evening milking. Milk samples $(50 \mathrm{~mL})$ were stored at $4^{\circ} \mathrm{C}$ with a preservative (bronopol tablet, D\&F Control System, San Ramon, CA) until analysis for milk composition. Additional, $50-\mathrm{mL}$ milk samples were stored at $-20^{\circ} \mathrm{C}$ until analysis for MUN.

Duplicate blood samples $(10 \mathrm{~mL})$ were collected on $\mathrm{d} 2,4,6$, and 8 of each phase from the coccygeal vein 2 to $3 \mathrm{~h}$ post morning feeding. One set of blood samples was collected in serum separator tubes (Serum Clot Activator, Greiner Bio-One GmbH, Kremsmunster, Austria), allowed to clot for a minimum of $30 \mathrm{~min}$ at room temperature, and stored at $4^{\circ} \mathrm{C}$ overnight. A second set of blood samples was obtained for plasma collection in vacuum tubes (lithium heparin, Greiner Bio-One GmbH) and immediately placed on ice. Both serum and plasma were harvested by centrifugation at $3,000 \times g$ for $15 \mathrm{~min}$ at $4^{\circ} \mathrm{C}$ and stored at $-20^{\circ} \mathrm{C}$ until further analysis.

On d 9 of each phase, samples of rumen fluid were collected twice (before and $3 \mathrm{~h}$ after the morning feeding) from each cow through a stomach tube. The initial aliquot of rumen fluid was discarded to eliminate saliva contamination. Immediately after collection, the fluid was strained through 4 layers of muslin cloth, the $\mathrm{pH}$ was measured with a portable electronic $\mathrm{pH}$ meter $(\mathrm{pH}$
Cube, TPS Pty Ltd., Springwood, QLD, Australia), and $10 \mathrm{~mL}$ was acidified with $0.1 \mathrm{~mL}$ of $6 \mathrm{M} \mathrm{HCl}$ for ammonia concentration determination. Another 10$\mathrm{mL}$ sample was collected for VFA and microbial CP (MCP) concentration analysis. All samples were stored at $-20^{\circ} \mathrm{C}$ until analysis.

\section{Analysis}

Daily mixed milk samples from each cow were analyzed by near mid infrared procedures using a Milk Oscan Minor machine (MilkoScan Type 78110, Foss Electric, Hillerød, Denmark). Milk urea nitrogen was analyzed by the diacetyl monoxide reagent colorimetric method using commercially available kits (catalog no. C013-1; Nanjing Jiancheng Bioengineering Institute, Nanjing, China).

Feed samples were dried at $65^{\circ} \mathrm{C}$ for $48 \mathrm{~h}$ (Mechanical Convection Oven, Freas 645, Thermo Electron Corp., Waltham, MA; Cheng et al., 2014) and ground through a 1-mm mesh screen using a Wiley mill (Arthur $\mathrm{H}$. Thomas Co., Philadelphia, PA) for subsequent DM $\left(105^{\circ} \mathrm{C}\right.$ for $\left.5 \mathrm{~h}\right), \mathrm{CP}$ (method 988.05; AOAC, 1990), ash (method 942.05; AOAC, 1990), and ADF (method 973.18; AOAC, 1990) analyses. In addition, the NDF content was determined using the Ankom A200 fiber analyzer (Ankom Technology, Macedon, NY), and previously reported methods (Van Soest et al., 1991), utilizing $\alpha$-amylase and sodium sulfide. Ether extract (EE) content was determined by a Soxtec system HT6 apparatus (Tecator AB, Hillerød, Denmark) according to AOAC (1990).

Fecal samples were dried at $65^{\circ} \mathrm{C}$ in a forced-air oven to constant weight and ground through a $1-\mathrm{mm}$ sieve. Samples were analyzed for ash, OM, CP, NDF, ADF, and $\mathrm{EE}$, as indicated above. Apparent total-tract digestibility of DM, OM, NDF, $\mathrm{ADF}, \mathrm{CP}$, and $\mathrm{EE}$ was calculated by using fecal nutrient content divided by the nutrient content of ingested feed. Urine was analyzed for urate and urea by an enzymatic method using commercially available kits (catalog no. C012 and C013-2, respectively; Nanjing Jiancheng Bioengineering Institute). The intra- and interassay coefficients of variation for the urate and urea assays were 5.5 and $2.9 \%$, and 4.7 and $2.9 \%$, respectively. The allantoin concentration of urine was determined as described by Borchers (1977). Intestinal microbial N flow was calculated according to Chen (1992) methods and equations, and MCP production was calculated as follows:

$$
\begin{aligned}
& \text { MCP production }(\mathrm{g} / \mathrm{d})=\frac{70}{0.116 \times 0.83 \times 1,000} \\
& \times \frac{\text { purine excretion }(\mathrm{mmol} / \mathrm{d})-0.385 \mathrm{BW}^{0.75}}{0.85} \times 6.25,
\end{aligned}
$$


where the $\mathrm{N}$ content of purines is $70 \mathrm{mg}$ of $\mathrm{N} / \mathrm{mmol}$; the digestibility of microbial purines is 0.83 ; the ratio of purine-N:total $\mathrm{N}$ in mixed rumen microbes is 0.116 ; purine excretion $=$ allantoin excretion + urate excretion; $\mathrm{BW}^{0.75}$ represents the metabolic BW $(\mathrm{kg})$ of the animal; $0.385 \mathrm{BW}^{0.75}$ represents the endogenous contribution of $\mathrm{PD}$; and the recovery of absorbed purines as $\mathrm{PD}$ in urine is 0.85 .

Serum samples were analyzed for nonesterified fatty acids (NEFA), glucose, and BUN concentrations using commercially available kits (A042-2, F006, and C013-2; Nanjing Jiancheng Bioengineering Institute). The intra- and interassay coefficients of variation were 2.4 and $5.6 \%, \leq 5$ and $\leq 5 \%$, and 4.7 and $2.9 \%$ for NEFA, glucose, and BUN, respectively. Blood free AA in serum samples were determined with an automatic analyzer (Hitachi Ltd., Tokyo, Japan), after trichloroacetic acid protein precipitation.

Rumen liquor filtrate $(5 \mathrm{~mL})$ was preserved by adding $1 \mathrm{~mL}$ of $25 \% \mathrm{HPO}_{3}$ (metaphosphoric acid) for determination of VFA content by gas chromatography (GC-8A, Shimadzu, Kyoto, Japan) as described by $\mathrm{Hu}$ et al. (2005). Rumen liquor ammonia-N concentration was measured using the alkaline phenol hypochlorite colorimetric procedure of Chaney and Marbach (1962).

\section{Statistical Analysis}

All data were statistically analyzed utilizing SAS version 9.3 (SAS Institute Inc., Cary, NC). The study was a crossover design with 2 periods, 2 treatments (during phase 2 of each period), and 2 groups of cows. Observations for each variable during the control phases (phase 1) were used as a covariate for the corresponding treatment phase (phase 2). Single measurements in each period such as digestibility, rumen liquor, nitrogen balance, BW loss, and urine parameters were analyzed using PROC MIXED. The model included sequence, treatment, and period as fixed effects; cow within sequence as a random effect, and the covariate, as follows:

$$
Y_{i j k}=\mu+b_{i j}+\pi_{k}+\varphi_{m}+c_{j}+b X_{i j k}+\varepsilon_{i j k},
$$

where $i=$ sequence, $j=$ cow, $k=$ period, and $m=$ treatment; $\mu=$ the overall mean; $b_{i j}=$ the effect of the $j$ th cow with $i$ th sequence and is $\sim N\left(0, \sigma_{b}^{2}\right) ; \pi_{k}=$ the effect of the $k$ th period; $\varphi_{m}=$ effect of $m$ th treatment; $c_{j}=$ random effect of $j$ th cow within sequence; $b X_{i j k}=$ effect of covariate; $\varepsilon_{i j k}=$ random error and is $\sim N(0$, $\sigma_{b}^{2}$ ), where $\sigma_{b}=$ the population standard deviation.

Variables with multiple measurements within the same period were analyzed using PROC MIXED with day of the treatment phase (phase 2) as the repeated ef- fect and compound symmetry for the covariance structure. Observations during phase 1 were averaged and used as a covariate for its corresponding phase 2 . The model included sequence, treatment, day, treatment $x$ day interaction, and period as fixed effects; cow within sequence as a random effect; day as repeated effect; and covariate as follows:

$$
\begin{aligned}
Y_{i j k}=\mu & +b_{i j}+\pi_{k}+\varphi_{m}+d_{l}+\varphi d_{m l} \\
& +c_{j}+b X_{i j k}+\varepsilon_{i j k l},
\end{aligned}
$$

where $i=$ sequence, $j=$ cow, $k=$ period, $l=$ day, and $m=$ treatment; $\mu=$ overall mean; $b_{i j}=$ the effect of the $j$ th cow with the $i$ th sequence and is $\sim N\left(0, \sigma_{b}^{2}\right) ; \pi_{k}=$ the effect of the $k$ th period; $\varphi_{m}=$ the effect of the $m$ th treatment; $d_{l}=$ the effect of the $l$ th day; $\varphi d_{m l}=$ the interaction effect of the $m$ th treatment by the lth day; $c_{j}=$ the random effect of the $j$ th cow within sequence; $b X_{i j k}=$ the effect of the covariate; $\varepsilon_{i j k}=$ the random error and is $\sim N\left(0, \sigma_{b}^{2}\right)$.

Data are reported as least squares means and considered significant if $P \leq 0.05$ and a tendency if $0.05<P$ $\leq 0.10$.

\section{RESULTS}

As expected, HS increased rectal temperature and respiration rate $\left(1.5^{\circ} \mathrm{C}\right.$ and 2.3 -fold, respectively; $P<$ 0.01) compared with PFTN conditions (Table 3). Heat stress decreased DMI (40.7\%) relative to the control phase, and DMI of PFTN cows was reduced similarly $(P=0.96)$, by experimental design (Table 3 ; Figure 1$)$.

The effects of HS on milk yield and milk composition are reported in Table 4 and Figure 1. Heat stress reduced milk yield $(17 \%, P<0.05)$, milk protein $(4.1 \%$, $P<0.01)$, protein yield $(19 \%, P<0.05)$, and FCM $(22.9 \%, P<0.05)$, compared with PFTN conditions. However, the efficiency was not different between treatments. Heat stress had no effect on milk lactose content, lactose yield, or milk fat content $(P>0.10)$, but milk fat yield was decreased compared with PFTN conditions $(19.3 \%, P<0.05)$, likely due to the overall reduction in milk yield. There were no treatment effects on milk total solid matter, but milk solid not fat was decreased in HS cows compared with PFTN controls $(3.6 \%, P<0.05)$.

The effects of HS on digestibility, and rumen fermentation and urine parameters are reported in Tables 5 and 6, respectively. Overall, HS cows had increased digestibility compared with PFTN controls (NDF 29.9\%, $\mathrm{DM} 17.6 \%, \mathrm{ADF} 42.9 \%$, CP $16.4 \%$, EE $11.1 \%$, OM $16.6 \% ; P<0.05)$. Rumen liquor ammonia-N concentration was or tended to be increased in HS cows compared 

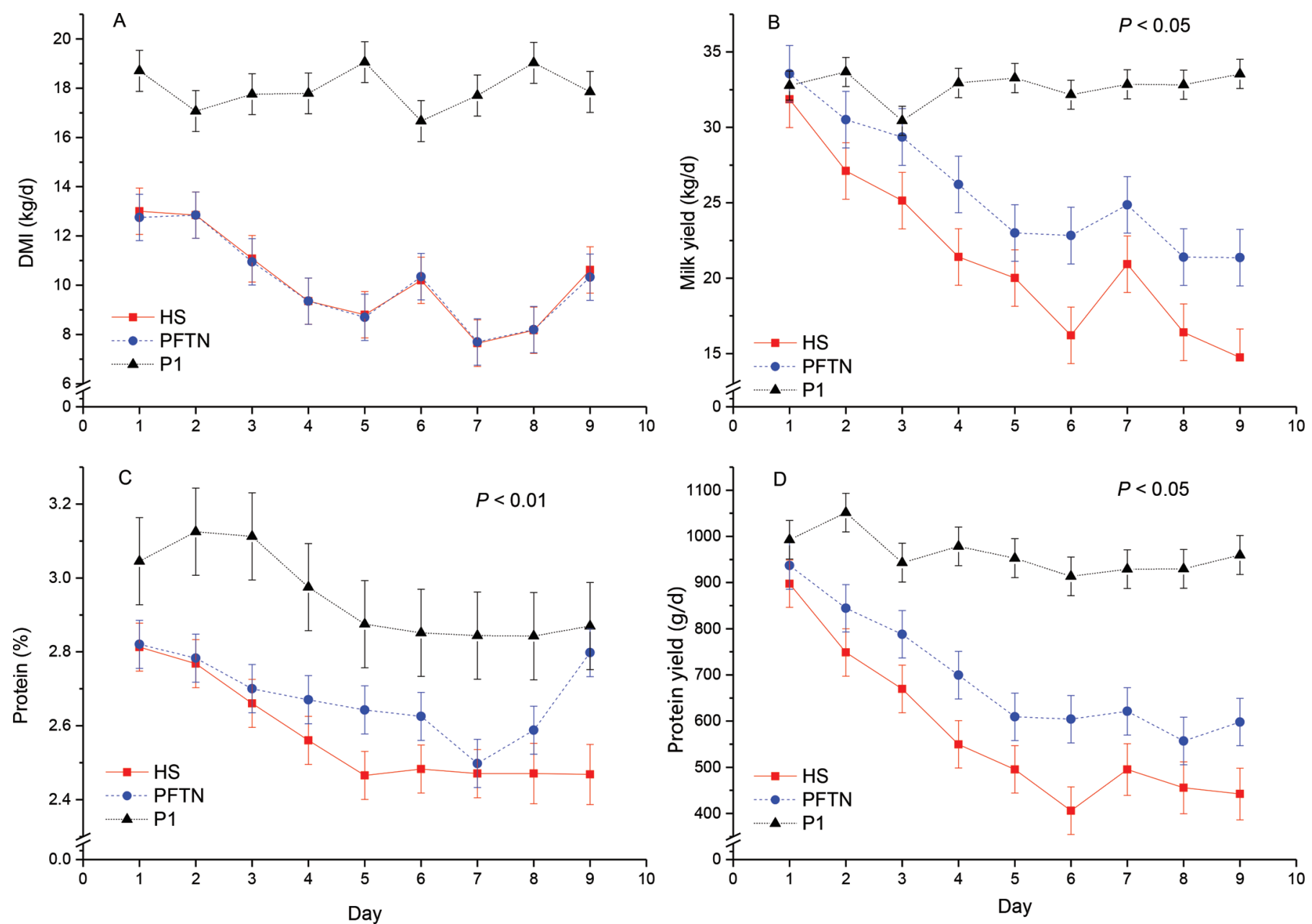

Figure 1. Effects of heat stress (HS) or pair-feeding on (A) DMI, (B) milk yield, (C) protein content, and (D) protein yield in lactating Holstein cows. Solid lines with squares represent HS cows, dashed lines with circles represent pair-fed thermal neutral (PFTN) cows, and dashed lines with triangles represent P1 cows in quadrants A, B, C, and D. P1 = average of the data of phase 1 in 2 periods. Error bars represent the SEM. Color version available online.

with PFTN controls both before $(33.2 \%, P<0.01)$ and after feeding $(29.5 \%, P<0.10)$. Heat stress decreased rumen liquor $\mathrm{pH}$ both before $(9.5 \%, P<0.01)$ and after feeding $(6 \%, P<0.05)$ compared with PFTN conditions. Microbial CP production was not different between treatments $(P=0.12)$, but was numerically increased in HS cows (14\%). Heat stress increased total VFA content before feeding $(45.3 \%, P<0.05)$ compared with PFTN conditions. After feeding there was no difference between 2 treatments, but the total VFA

Table 3. Temperature-humidity index (THI) and effects of pair-feeding or heat stress on body temperature indices and feed intake ${ }^{1}$

\begin{tabular}{|c|c|c|c|c|c|c|c|c|}
\hline \multirow[b]{2}{*}{ Item } & \multirow[b]{2}{*}{$\mathrm{P} 1^{2}$} & \multicolumn{2}{|c|}{ Treatment } & \multirow[b]{2}{*}{ SEM } & \multicolumn{4}{|c|}{$P$-value } \\
\hline & & PFTN & HS & & Trt & Trt $\times$ day & Period & Sequence \\
\hline$\overline{\mathrm{THI}}$ & 64.2 & 64.6 & 82.4 & 0.50 & 0.0008 & 0.4696 & 0.9686 & 0.9001 \\
\hline RR (bpm) & 35.7 & 33.3 & 77.8 & 0.31 & $<0.0001$ & 0.2312 & $<0.0001$ & 0.1112 \\
\hline $\operatorname{RT}\left({ }^{\circ} \mathrm{C}\right)$ & 38.5 & 38.5 & 40.0 & 0.08 & 0.0026 & 0.6755 & 0.1504 & 0.4440 \\
\hline DMI (kg) & 17.4 & 10.1 & 10.2 & 1.07 & 0.9597 & 1.0000 & 0.0626 & 0.6742 \\
\hline
\end{tabular}

${ }^{1} \mathrm{PFTN}=$ pair-fed thermal neutral; $\mathrm{HS}=$ heat stress; Trt $=$ treatment; $\mathrm{RR}=$ respiratory rate; $\mathrm{RT}=$ rectal temperature.

${ }^{2}$ Average of the data of phase 1 in 2 periods. 
Table 4. Effect of heat stress or pair-feeding on milk yield and milk compositions

\begin{tabular}{|c|c|c|c|c|c|c|c|c|}
\hline Item & $\mathrm{P} 1^{1}$ & \multicolumn{2}{|c|}{ Treatment $^{2}$} & SEM & \multicolumn{4}{|c|}{$P$-value } \\
\hline Efficiency $^{4}$ & 1.84 & 2.85 & 2.39 & 0.287 & 0.2048 & 0.0075 & 0.0260 & 0.2429 \\
\hline Protein (\%) & 2.95 & 2.68 & 2.57 & 0.017 & 0.0076 & 0.2087 & 0.0006 & 0.3629 \\
\hline Protein yield (g/d) & 961 & 705 & 571 & 39.0 & 0.0409 & 0.6783 & 0.1688 & 0.2518 \\
\hline Fat yield (g/d) & 1,163 & 1,096 & 884 & 44.9 & 0.0381 & 0.8951 & 0.1496 & 0.2652 \\
\hline Lactose $(\%)$ & 4.79 & 4.82 & 4.68 & 0.094 & 0.2362 & 0.7097 & 0.8272 & 0.7646 \\
\hline Lactose yield (g/d) & 1,567 & 1,235 & 1,021 & 80.4 & 0.1166 & 0.9589 & 0.6223 & 0.9641 \\
\hline Solid matter (\%) & 11.49 & 12.02 & 11.81 & 0.1246 & 0.2241 & 0.7761 & 0.9245 & 0.4955 \\
\hline MSNF (\%) & 16.41 & 8.06 & 7.77 & 0.088 & 0.0451 & 0.6647 & 0.0044 & 0.9903 \\
\hline
\end{tabular}

${ }^{1}$ Average of the data of phase 1 in 2 periods.

${ }^{2} \mathrm{PFTN}=$ pair-fed thermal neutral; HS $=$ heat stress.

${ }^{3} 4 \% \mathrm{FCM}=0.4(\mathrm{~kg}$ of milk) +15.0 ( $\mathrm{kg}$ of fat $)$.

${ }^{4}$ Efficiency $=4 \% \mathrm{FCM} / \mathrm{DMI}$.

${ }^{5} \mathrm{MSNF}=$ milk solid not fat.

content of HS was numerically increased in HS cows (22\%) compared with PFTN. The heat-induced VFA increase was due to increased acetate $(42.1$ and $20 \%, P$ $<0.10)$, and butyrate $(2.65$-fold and $41.6 \%, P<0.10)$ concentrations before and after feeding, respectively. In addition, HS cows had increased valerate $(46.7 \% ; P$ $=0.05)$ and propionate $(58.9 \%, P<0.05)$ concentrations only before feeding, and acetic to propionic acid ratio was or tended to be decreased $(30.9 \%$ and $7.2 \%$, $P<0.10)$ both before and after feeding compared with PFTN controls. Both urinary urea nitrogen (UUN) and MUN were increased in HS compared with PFTN conditions (3.4-fold and $24.5 \%$, respectively; $P<0.05$ ). The effects of HS on nitrogen balance are reported in Table 7 . Heat stress decreased milk nitrogen excretion $(P<0.05)$. However, no differences were observed in fecal or urinary nitrogen excretion, or nitrogen retention between treatments.

The effects of HS on blood parameters are reported in Table 8. Heat stress tended to decrease and decreased plasma glucose $(8 \%, P<0.10)$ and NEFA $(39.8 \%$, $P<0.05)$, respectively; and tended to increase BUN $(14.7 \%, P<0.1)$ compared with PFTN controls. Heat stress cows had reduced total plasma AA $(17.1 \%, P<$ 0.05 ), including some essential (Ile $42.5 \%$, Lys $18.2 \%$, $P<0.05$ ) and nonessential (Ser 10.7\%, Arg 25.1\%, Gly $20.8 \%$, Cys $27 \%, P<0.05)$ AA. In addition, Thr, Glu, Leu, and Asp tended to be reduced (10.8-32.1\%, $P<$ $0.10)$ in HS animals compared with PFTN cows.

\section{DISCUSSION}

Heat stress has detrimental consequences for animal welfare and productivity, constituting an economic burden on the global dairy industry. Decreased feed intake is a conserved response among HS animals and is presumably an attempt to reduce metabolic heat production (Fuquay, 1981; Beede and Collier, 1986; West, 2003). Nevertheless, hyperthermia-induced hypophagia cannot fully explain production losses, as demonstrated

Table 5. Effect of pair-feeding or heat stress on digestibility

\begin{tabular}{|c|c|c|c|c|c|c|c|}
\hline \multirow[b]{2}{*}{ Item } & \multirow[b]{2}{*}{$\mathrm{P} 1^{1}$} & \multicolumn{2}{|c|}{ Treatment $^{2}$} & \multirow[b]{2}{*}{ SEM } & \multicolumn{3}{|c|}{$P$-value } \\
\hline & & PFTN & HS & & Treatment & Period & Sequence \\
\hline NDF $(\%)$ & 62.0 & 53.3 & 76.0 & 5.16 & 0.0219 & 0.9014 & 0.3690 \\
\hline $\mathrm{DM}(\%)$ & 73.8 & 68.7 & 83.4 & 2.96 & 0.0382 & 0.5432 & 0.8937 \\
\hline $\mathrm{ADF}(\%)$ & 48.1 & 37.3 & 65.3 & 7.36 & 0.0317 & 0.4688 & 0.3631 \\
\hline $\mathrm{CP}(\%)$ & 73.2 & 69.5 & 83.1 & 2.80 & 0.0401 & 0.9182 & 0.4516 \\
\hline Ether extract (\%) & 86.3 & 81.0 & 91.1 & 2.53 & 0.0281 & 0.5484 & 0.5552 \\
\hline OM (\%) & 75.7 & 70.7 & 84.8 & 3.31 & 0.0238 & 0.8755 & 0.3751 \\
\hline
\end{tabular}

${ }^{1}$ Average of the data of phase 1 in 2 periods.

${ }^{2} \mathrm{PFTN}=$ pair-fed thermal neutral; HS $=$ heat stress. 
GAO ET AL.

Table 6. Effect of pair-feeding or heat stress on rumen fermentation and urea in urine

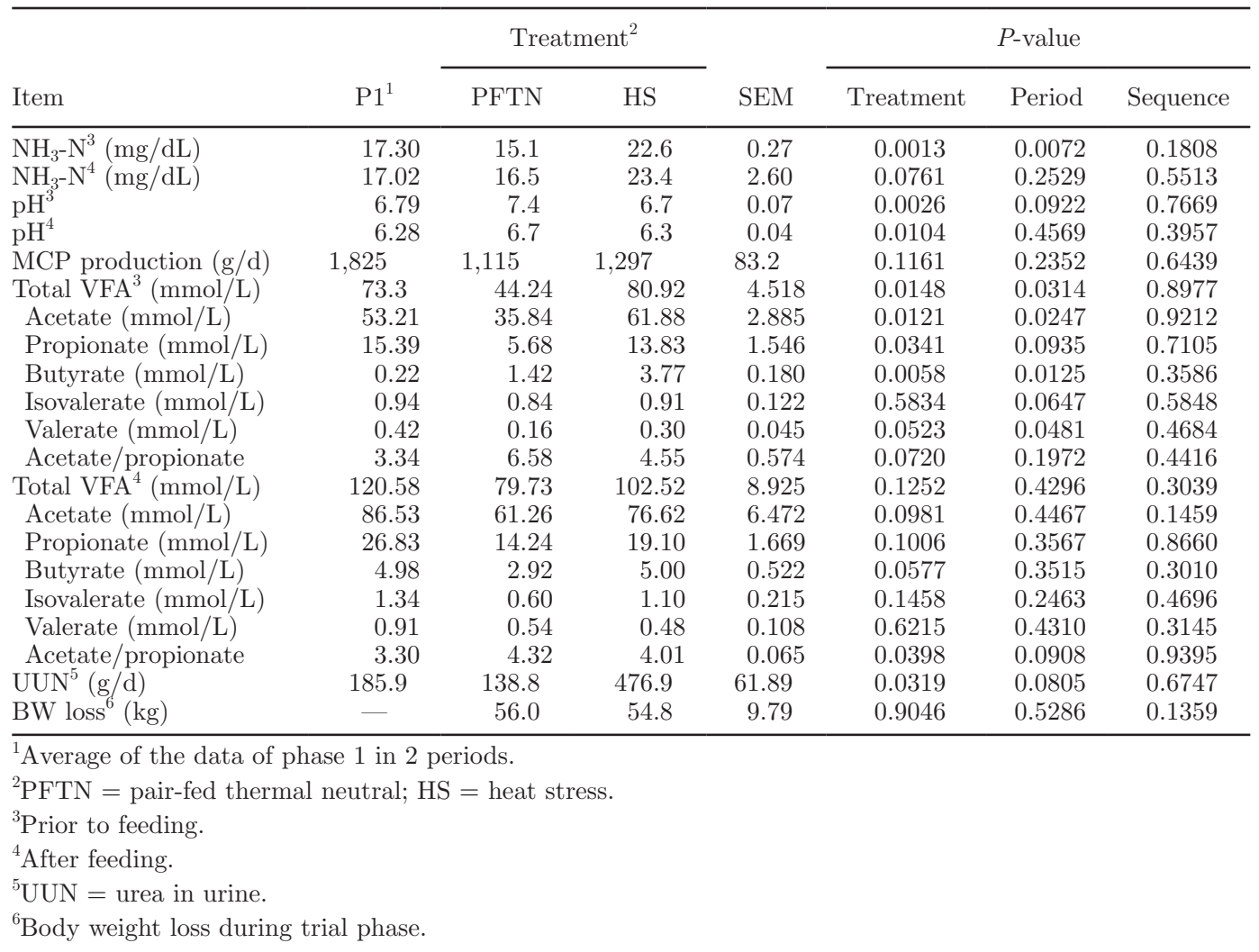

by the use of PFTN models (Rhoads et al., 2009; Wheelock et al., 2010; Cowley et al., 2015). Recent data indicate that high-yielding dairy cows started to reduce milk yield at a THI of approximately 68 (Zimbelman et al., 2009). In the current study, dairy cows were exposed to conditions well above this threshold (average THI $=$ 82.4), causing hyperthermia, tachypnea, and marked DMI reductions (Table 3). In agreement with previous reports and despite similar DMI (Figure 1A), HS cows experienced a more severe milk yield loss compared with PFTN cows (Table 3), suggesting a direct effect of HS on milk production, independent of intake as has been reported by others (Baumgard and Rhoads, 2012; Cowley et al., 2015). In the present study, the value of efficiency $(2.36 \sim 2.79)$ was much higher than excepted, which may have accounted for the short exposure to HS and it would presumably return to a normal level if the exposure was prolonged.

Environmentally induced hyperthermia not only affects overall milk production, but also milk composition. Consistent with previous studies (Bandaranayaka and Holmes, 1976; Rhoads et al., 2009; Cowley et al., 2015), milk protein concentration was decreased in HS cows compared with PFTN controls. The mechanisms regulating milk protein synthesis during HS are largely unknown, but likely involve changes in several biological systems. Reasons for reduced milk protein might be intrinsic to the mammary gland. For example, Cowley

Table 7. Effect of pair-feeding or heat stress on nitrogen balance

\begin{tabular}{|c|c|c|c|c|c|c|c|}
\hline \multirow[b]{2}{*}{ Item } & \multirow[b]{2}{*}{$\mathrm{P} 1^{1}$} & \multicolumn{2}{|c|}{ Treatment $^{2}$} & \multirow[b]{2}{*}{ SEM } & \multicolumn{3}{|c|}{$P$-value } \\
\hline & & PFTN & HS & & Treatment & Period & Sequence \\
\hline $\mathrm{N}$ intake $(\mathrm{g} / \mathrm{d})$ & 452.4 & 238.7 & 237.7 & 32.957 & 0.9772 & 0.3235 & 0.6557 \\
\hline Fecal N (g/d) & 121.3 & 72.6 & 45.2 & 10.911 & 0.1287 & 0.2492 & 0.5375 \\
\hline Urinary N (g/d) & 231.1 & 114.4 & 129.2 & 19.08 & 0.4947 & 0.8705 & 0.3988 \\
\hline Milk N (g/d) & 169.0 & 96.9 & 72.1 & 6.442 & 0.0310 & 0.0880 & 0.0845 \\
\hline $\mathrm{N}$ retention $(\mathrm{g} / \mathrm{d})$ & -69.1 & -45.2 & -8.8 & 38.181 & 0.4112 & 0.9645 & 0.4333 \\
\hline
\end{tabular}

${ }^{1}$ Average of the data of phase 1 in 2 periods.

${ }^{2} \mathrm{PFTN}=$ pair-fed thermal neutral; HS $=$ heat stress. 
Table 8. Effect of pair-feeding or heat stress on milk protein precursors and nonesterified fatty acids (NEFA)

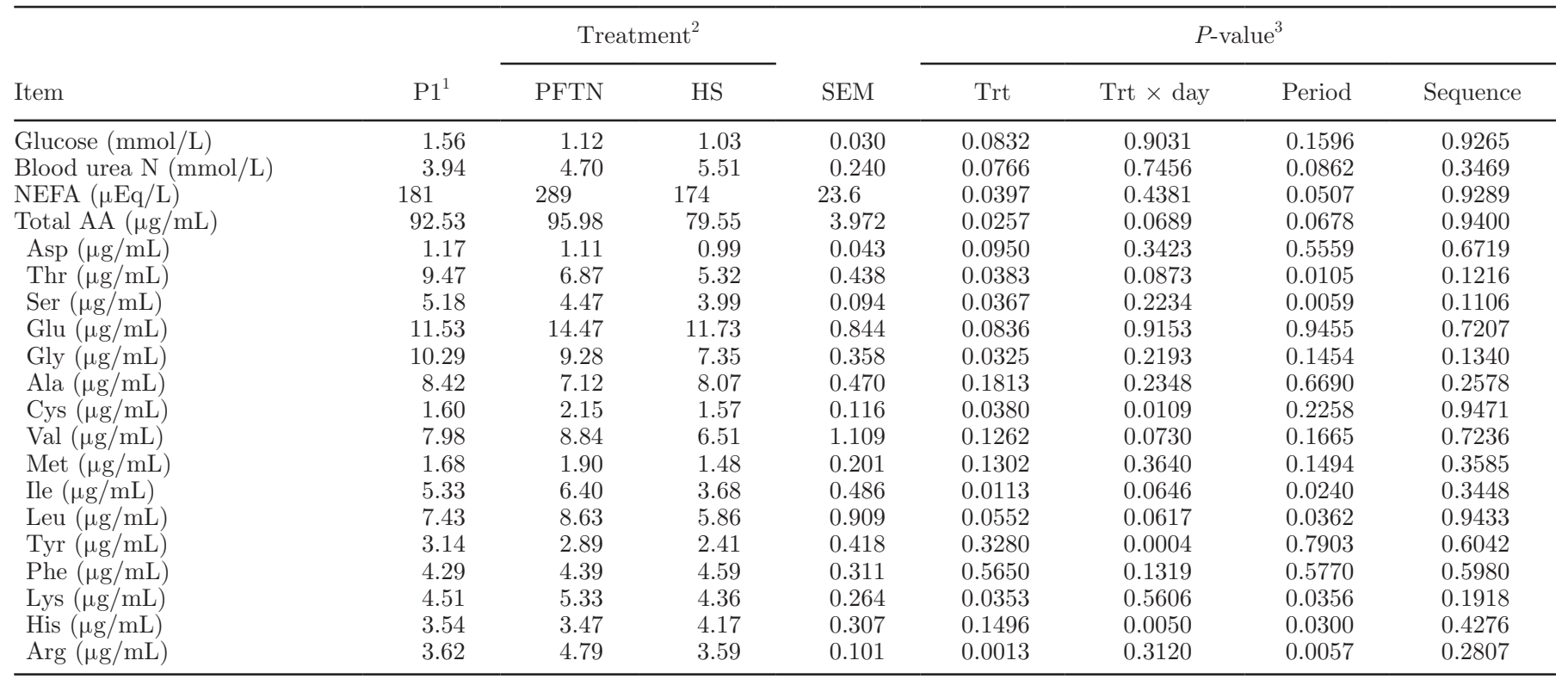

${ }^{1}$ Average of the data of phase 1 in 2 periods.

${ }^{2} \mathrm{PFTN}=$ pair-fed thermal neutral; HS $=$ heat stress.

${ }^{3}$ Trt $=$ treatment.

et al. (2015) demonstrated that these reductions in milk protein of heat-stressed cows appear to be a result of specific downregulation of mammary protein synthetic activity and are not artifacts of a general reduction in milk yield. Furthermore, decreased milk protein during HS might be the result of increased protein turnover, AA competition between casein and structural proteins, as well as increased casein degradation (Bequette and Backwell, 1997).

In addition to mammary gland intrinsic mechanisms, hyperthermia-induced milk protein reductions might be the result of limitations in the precursor supply caused by the reduction in mammary blood flow. Lough et al. (1990), utilizing a similar experimental design to ours, observed that both HS and feed restriction decreased mammary perfusion similarly, compared with TN ad libitum-fed cows. Changes in ruminal protein metabolism might also restrict milk protein precursor availability during HS. For example, Bernabucci and Calamari (1998) observed a decrease in rumen MCP synthesis in HS cows. In contrast, others have demonstrated that the HS-induced increased water consumption might accelerate microbial passage rate (Schneider et al., 1988) and enhance microbial growth (Kadzere et al., 2002), and ultimately MCP synthesis. In the current study, no differences were detectable in MCP synthesis between treatments, probably due to the fact that PFTN consumed a similar amount of dietary protein. Additionally, reduced splanchnic blood flow may also limit AA absorption. For example, McGuire et al.
(1989) reported that portal flow tended to decrease during HS, although it was better correlated with the level of DMI rather than ambient temperature.

Additionally, heat-induced alterations in nutrient partitioning might reduce the delivery of protein precursors to the mammary gland. In agreement, HS cows had reduced plasma free AA, and increased BUN, MUN, and UUN (presumably mostly by-products of AA deamination), which, combined with similar MCP synthesis and decreased milk protein output, suggests increased whole-body AA utilization. It is worth noting that increased BUN can also result from reduced incorporation of rumen ammonia into MCP (Cowley et al., 2015). In the present experiment, rumen liquor ammonia concentration was elevated, in agreement with previous reports (Mishra et al., 1970). Thus, we cannot exclude altered rumen function as a source of elevated BUN. Nevertheless, reasons behind the increase in rumen liquor ammonia are still undetermined but of practical and academic interest.

Despite an apparent increase in AA requirements during HS, AA fate remains unknown. We and others (Colditz and Kellaway, 1972; Ronchi et al., 1999) have hypothesized that the contribution of AA to the circulating glucose pool is increased during HS. In the present study, $78 \%$ of plasma AA reduction was due to the decline in gluconeogenic AA. Increased whole-body glucose utilization is a conserved response to environmental hyperthermia reported in various species: cows (Ronchi et al., 1997; Rhoads et al., 2009; Baumgard et 
al., 2011), pigs (Victoria Sanz Fernandez et al., 2015), rodents (Miova et al., 2014), goats (Okoruwa, 2014), and so on. In agreement, in this study HS cows tended to have more severe hypoglycemia compared with PFTN controls. Such an increase is thought to occur at the expense of adipose tissue mobilization (Baumgard and Rhoads, 2013) as this study and others have demonstrated that HS lactating cows have decreased circulating NEFA, compared with PFTN cows (Bertoni, 1998; Ronchi et al., 1999; Rhoads et al., 2009; Victoria Sanz Fernandez et al., 2015). Taken together, these data suggest that the decline in plasma AA experienced during HS might be the result of an increase in AA utilization as gluconeogenic precursors.

Apart from their contribution to gluconeogenesis, endogenous protein stores, might have alternative fates interfering with milk protein synthesis during HS. Previous results in HS cattle and buffalo showed that a $>200$-fold increase in heat shock protein 70 levels in blood lymphocytes compared with controls (Mishra et al., 2011). As part of the response to hyperthermia, heat shock proteins protect other proteins from heatinduced denaturalization (Collier et al., 2008). In agreement, Collier et al. (2008) reported that heat shock protein expression increased with exposure to severe HS in dairy cows. Thus, the synthesis of these heat shock proteins may reduce the availability of circulating AA for milk protein synthesis (Cowley et al., 2015).

Although not always consistent (Miaron and Christopherson, 1992; Bernabucci et al., 1999; Bernabucci et al., 2009), we demonstrated that HS increased the digestibility of NDF, ADF, CP, EE, OM, and DM, and this agrees with others (Westra and Christopherson, 1976; Christopherson and Kennedy, 1983; Beede and Collier, 1986). The increase in digestibility normally observed in HS is ostensibly due to decreased feed intake and the subsequent decrease in passage rate (Warren et al., 1974; Van Soest, 1994; Mulligan et al., 2001). However, we unexpectedly detected an increase in nutrient digestibility in HS cows compared with the PFTN controls. Thus, reduced DMI cannot directly account for the increase of digestibility and an overt explanation is not clear. One possibility is that gastrointestinal motility is decreased in HS compared with the PFTN cows and this would likely increase retention time (Christopherson and Kennedy, 1983). An additional unknown is how increased water consumption (and resulting increased water passage rate) during HS affects digestion kinetics and location (within the tract) of digestion (Baumgard and Rhoads, 2013). Unexplainably, our digestibility values are higher than often reported in the literature (Bernabucci et al., 1999, 2009); regardless, having a better understanding of how HS affects a variety of digestibility characteristics would be of both academic and industry interest.

\section{CONCLUSIONS}

Heat stress had direct effects on protein metabolism and productivity, including decreased milk protein content and yield. It is clear that the decline in milk yield and milk protein cannot be completely explained by the decreased DMI. The decrease in plasma AA and increase in BUN, MUN, and UUN, combined with similar MCP synthesis, suggest that increased extramammary AA consumption occurs during HS. Thus, the decrease in milk protein observed during HS might be the result of a lack of available precursors supplied to the mammary gland. In conclusion, it appears blood AA utilization is reprioritized away from milk protein synthesis during HS.

\section{ACKNOWLEDGMENTS}

The present study was financially supported by National Natural Science Foundation of China (313372341), Ministry of Science and Technology of China (No.2012BAD12B02-5), and Agricultural Science and Technology Innovation Program (ASTIPIAS07). We especially give thanks to our former and current students who have contributed to the projects and all the staff of the State Key Laboratory of Animal Nutrition (Beijing, China) for the use of environmental chambers and for sample analyses.

\section{REFERENCES}

AOAC. 1990. Official Methods of Analysis of AOAC International, 14th ed. Vol. 1. Association of Official Analytical Chemists, Arlington, VA.

Bandaranayaka, D. D., and C. W. Holmes. 1976. Changes in the composition of milk and rumen contents in cows exposed to a high ambient temperature with controlled feeding. Trop. Anim. Health Prod. 8:38-46.

Baumgard, L. H., and R. P. Rhoads. 2012. Ruminant Nutrition Symposium: Ruminant production and metabolic responses to heat stress. J. Anim. Sci. 90:1855-1865.

Baumgard, L. H., and R. P. Rhoads. 2013. Effects of heat stress on postabsorptive metabolism and energetics. Annu. Rev. Anim. Biosci. 1:311-337.

Baumgard, L. H., J. B. Wheelock, S. R. Sanders, C. E. Moore, H. B. Green, M. R. Waldron, and R. P. Rhoads. 2011. Postabsorptive carbohydrate adaptations to heat stress and monensin supplementation in lactating Holstein cows. J. Dairy Sci. 94:5620-5633.

Beede, D. K., and R. J. Collier. 1986. Potential nutritional strategies for intensively managed cattle during thermal stress. J. Anim. Sci. $62: 543-554$.

Bequette, B. J., and F. R. C. Backwell. 1997. Amino acid supply and metabolism by the ruminant mammary gland. Proc. Nutr. Soc. 56:593-605.

Bernabucci, U., P. Bani, B. Ronchi, N. Lacetera, and A. Nardone. 1999. Influence of short- and long-term exposure to a hot environ- 
ment on rumen passage rate and diet digestibility by Friesian heifers. J. Dairy Sci. 82:967-973.

Bernabucci, U., L. Basirico, P. Morera, D. Dipasquale, A. Vitali, F. P. Cappelli, and L. Calamari. 2015. Effect of summer season on milk protein fractions in Holstein cows. J. Dairy Sci. 98:1815-1827.

Bernabucci, U., and L. Calamari. 1998. Effects of heat stress on bovine milk yield and composition. Zootecnica e Nutrizione Animale 24:247-257.

Bernabucci, U., N. Lacetera, P. P. Danieli, P. Bani, A. Nardone, and B. Ronchi. 2009. Influence of different periods of exposure to hot environment on rumen function and diet digestibility in sheep. Int. J. Biometeorol. 53:387-395.

Bertoni, G. 1998. Effects of heat stress on endocrine-metabolic and reproductive status of the dairy cows. Zootecnica e Nutrizione Animale 24:273-282.

Borchers, R. 1977. Allantoin determination. Anal. Biochem. 79:612613.

Chaney, A. L., and E. P. Marbach. 1962. Modified reagents for determination of urea and ammonia. Clin. Chem. 8:130-132.

Chen, X. B., and M. J. Gomes. 1992. Estimation of microbial protein supply to sheep and cattle based on urinary excretion of purine derivatives - An overview of the technical details. International Feed Resources Unit, Rowett Research Institute, Bucksburn, Aberdeen, UK. Occasional Publication 1992

Cheng, J. B., D. P. Bu, J. Q. Wang, X. Z. Sun, L. Pan, L. Y. Zhou, and W. Liu. 2014. Effects of rumen-protected y-aminobutyric acid on performance and nutrient digestibility in heat-stressed dairy cows. J. Dairy Sci. 97:5599-5607.

Christopherson, R. J., and P. M. Kennedy. 1983. Effect of the thermal environment on digestion in ruminants. Can. J. Anim. Sci. 63:477-496.

Colditz, P. J., and R. C. Kellaway. 1972. The effect of diet and heat stress on feed intake, growth, and nitrogen metabolism in Friesian, F1 Brahman X Friesian, and Brahman heifers. Aust. J. Agric. Res. 23:717-725.

Collier, R. J., J. L. Collier, R. P. Rhoads, and B. Lh. 2008. Invited review: Genes involved in the bovine heat stress response. J. Dairy Sci. 91:445-454.

Cowley, F. C., D. G. Barber, A. V. Houlihan, and D. P. Poppi. 2015. Immediate and residual effects of heat stress and restricted intake on milk protein and casein composition and energy metabolism. J. Dairy Sci. 98:2356-2368.

Fuquay, J. W. 1981. Heat stress as it affects animal production. J. Anim. Sci. 52:164-174.

Hu, W. L., J. X. Liu, J. A. Ye, Y. M. Wu, and Y. Q. Guo. 2005. Effect of tea saponin on rumen fermentation in vitro. Anim. Feed Sci. Technol. 120:333-339.

Kadzere, C. T., M. R. Murphy, N. Silanikove, and E. Maltz. 2002. Heat stress in lactating dairy cows: A review. Livest. Prod. Sci. 77:59-91.

Lough, D. S., D. L. Beede, and C. J. Wilcox. 1990. Effects of feed intake and thermal stress on mammary blood flow and other physiological measurements in lactating dairy cows. J. Dairy Sci. 73:325-332.

McGuire, M. A., D. K. Beede, M. A. DeLorenzo, C. J. Wilcox, G. B. Huntington, C. K. Reynolds, and R. J. Collier. 1989. Effects of thermal stress and level of feed intake on portal plasma flow and net fluxes of metabolites in lactating Holstein cows. J. Anim. Sci. 67:1050-1060.

Miaron, J., and R. J. Christopherson. 1992. Effect of prolonged thermal exposure on heat production, reticular motility, rumen-fluid and particulate passage-rate constants, and apparent digestibility in steers. Can. J. Anim. Sci. 4:809-819.

Miova, B., S. Dinevska-Kjovkarovska, A. Djimrevska, and S. Mitev. 2014. Prior heat stress induces moderation of diabetic alterations in glycogen metabolism of rats. Cent. Eur. J. Biol. 9:249-259.
Mishra, A., O. K. Hooda, G. Singh, and S. K. Meur. 2011. Influence of induced heat stress on HSP70 in buffalo lymphocytes. J. Anim. Physiol. Anim. Nutr. (Berl.) 95:540-544.

Mishra, M., F. A. Martz, R. W. Stanley, H. D. Johnson, J. R. Campbell, and E. Hilderbrand. 1970. Effect of diet and ambient temperature-humidity on ruminal $\mathrm{pH}$, oxidation reduction potential, ammonia and lactic acid in lactating cows. J. Anim. Sci. 30:65-69.

Mulligan, F. J., P. J. Caffrey, M. Rath, J. J. Callan, and F. P. O'Mara. 2001. The relationship between feeding level, rumen particulate and fluid turnover rate and the digestibility of soya hulls in cattle and sheep (including a comparison of Cr-mordanted soya hulls and $\mathrm{Cr}_{2} \mathrm{O}_{3}$ as particulate markers in cattle). Livest. Prod. Sci. 70:191-202.

NRC. 2001. Nutrient Requirements of Dairy Cattle. 7th rev. ed. The National Academies Press, Washington, DC.

Okoruwa, M. I. 2014. Effect of heat stress on thermoregulatory, live bodyweight and physiological responses of dwarf goats in southern Nigeria. Eur. Sci. J. 10:255-264.

Rhoads, M. L., R. P. Rhoads, M. J. VanBaale, R. J. Collier, S. R. Sanders, W. J. Weber, B. A. Crooker, and L. H. Baumgard. 2009. Effects of heat stress and plane of nutrition on lactating Holstein cows: I. Production, metabolism, and aspects of circulating somatotropin. J. Dairy Sci. 92:1986-1997.

Ronchi, B., U. Bernabucci, N. Lacetera, and A. Nardone. 1997. Effects of heat stress on metabolic-nutritional status of Holstein cows Effetti dello stress termico sullo stato metabolico-nutrizionale di vacche Frisone in lattazione. Zootecnica e Nutrizione Animale 23:3-15.

Ronchi, B., U. Bernabucci, N. Lacetera, A. Verini Supplizi, and A. Nardone. 1999. Distinct and common effects of heat stress and restricted feeding on metabolic status of Holstein heifers. Zootecnica e Nutrizione Animale 25:11-20.

Schneider, P. L., D. K. Beede, and C. J. Wilcox. 1988. Nycterohemeral patterns of acid-base status, mineral concentrations and digestive function of lactating cows in natural or chamber heat stress environments. J. Anim. Sci. 66:112-125.

Van Soest, P. J. 1994. Nutritional Ecology of the Ruminant. 44:25522561. Cornell University Press, Ithaca, NY.

Van Soest, P. J., J. B. Robertson, and B. A. Lewis. 1991. Methods for dietary fiber, neutral detergent fiber, and nonstarch polysaccharides in relation to animal nutrition. J. Dairy Sci. 74:3583-3597.

Victoria Sanz Fernandez, M., J. S. Johnson, M. Abuajamieh, S. K. Stoakes, J. T. Seibert, L. Cox, S. Kahl, T. H. Elsasser, J. W. Ross, S. C. Isom, R. P. Rhoads, and L. H. Baumgard. 2015. Effects of heat stress on carbohydrate and lipid metabolism in growing pigs. Physiol. Rep. 3:e12315.

Warren, W. P., F. A. Martz, K. H. Asay, E. S. Hilderbrand, C. G. Payne, and J. R. Vogt. 1974. Digestibility and rate of passage by steers fed tall fescue, alfalfa and orchardgrass hay in 18 and $32 \mathrm{C}$ ambient temperatures. J. Anim. Sci. 39:93-96.

West, J. W. 1994. Interactions of energy and bovine somatotropin with heat stress. J. Dairy Sci. 77:2091-2102.

West, J. W. 2003. Effects of heat-stress on production in dairy cattle. J. Dairy Sci. 86:2131-2144.

Westra, R., and R. J. Christopherson. 1976. Effects of cold on digestibility, retention time of digesta, reticulum motility and thyroid hormones in sheep. Can. J. Anim. Sci. 56:699-708.

Wheelock, J. B., R. P. Rhoads, M. J. VanBaale, S. R. Sanders, and L. H. Baumgard. 2010. Effects of heat stress on energetic metabolism in lactating Holstein cows. J. Dairy Sci. 93:644-655.

Zimbelman, R. B., R. P. Rhoads, M. L. Rhoads, G. C. Duff, L. H Baumgard, and R. J. Collier. 2009. A re-evaluation of the impact of temperature humidity index (THI) and black globe humidity index (BGHI) on milk production in high producing dairy cows. Pages 113-126 in IEICE Technical Report ASN Ambient Intelligence \& Sensor Networks, vol. 113. 